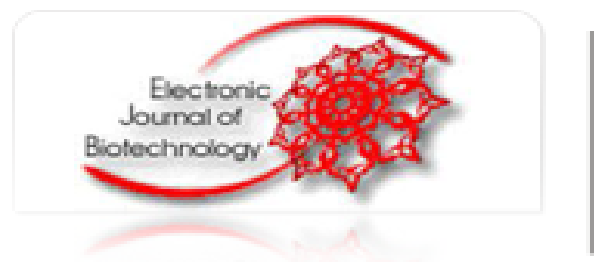

Electronic Journal of Biotechnology

E-ISSN: 0717-3458

edbiotec@ucv.cl

Pontificia Universidad Católica de Valparaíso Chile

Hsiao, Nai-Wan; Chen, Yeh; Kuan, Yi-Chia; Lee, Yen-Chung; Lee, Shuo-Kang; Chan, Hsin-Hua; Kao, Chao-Hung

Purification and characterization of an aspartic protease from the Rhizopus oryzae protease extract, Peptidase R

Electronic Journal of Biotechnology, vol. 17, núm. 2, 2014, pp. 1-6

Pontificia Universidad Católica de Valparaíso

Valparaíso, Chile

Available in: http://www.redalyc.org/articulo.oa?id=173330098006

How to cite

Complete issue

- More information about this article

Journal's homepage in redalyc.org

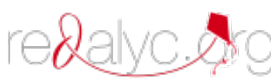

Scientific Information System Network of Scientific Journals from Latin America, the Caribbean, Spain and Portugal Non-profit academic project, developed under the open access initiative 


\title{
Purification and characterization of an aspartic protease from the Rhizopus oryzae protease extract, Peptidase R
}

\author{
Nai-Wan Hsiao ${ }^{\mathrm{a}, 1}$, Yeh Chen ${ }^{\mathrm{b}, 1}$, Yi-Chia Kuan ${ }^{\mathrm{b}, \mathrm{c}}$, Yen-Chung Lee ${ }^{\mathrm{d}}$, Shuo-Kang Lee ${ }^{\mathrm{b}}$, \\ Hsin-Hua Chan ${ }^{\mathrm{b}}$, Chao-Hung Kao ${ }^{\mathrm{b}, *}$ \\ a Institute of Biotechnology, National Changhua University of Education, Changhua 500, Taiwan \\ b Department of Biotechnology, Hungkuang University, Taichung 433, Taiwan \\ c Department of Life Science, National Tsing Hua University, Hsinchu 300, Taiwan \\ d Department of Bioagricultural Science, National Chiayi University, Chiayi 600, Taiwan
}

\section{A R T I C L E I N F O}

\section{Article history:}

Received 2 September 2013

Accepted 14 January 2014

Available online $\mathrm{xxxx}$

\section{Keywords:}

chromatography

Endopeptidase

Food processing industry

Homogeneity

Rhizopuspepsin

\begin{abstract}
A B S T R A C T
Background: Aspartic proteases are a subfamily of endopeptidases that are useful in a variety of applications, especially in the food processing industry. Here we describe a novel aspartic protease that was purified from Peptidase R, a commercial protease preparation derived from Rhizopus oryzae.

Results: An aspartic protease sourced from Peptidase R was purified to homogeneity by anion exchange chromatography followed by polishing with a hydrophobic interaction chromatography column, resulting in a 3.4-fold increase in specific activity $\left(57.5 \times 10^{3} \mathrm{U} / \mathrm{mg}\right)$ and $58.8 \%$ recovery. The estimated molecular weight of the purified enzyme was $39 \mathrm{kDa}$. The $\mathrm{N}$-terminal sequence of the purified protein exhibited $63 \%-75 \%$ identity to rhizopuspepsins from various Rhizopus species. The enzyme exhibited maximal activity at $75^{\circ} \mathrm{C}$ in glycine- $\mathrm{HCl}$ buffer, $\mathrm{pH} 3.4$ with casein as the substrate. The protease was stable at $35^{\circ} \mathrm{C}$ for $60 \mathrm{~min}$ and had an observed half-life of approximately $30 \mathrm{~min}$ at $45^{\circ} \mathrm{C}$. Enzyme activity was not significantly inhibited by chelation with ethylenediamine tetraacetic acid (EDTA), and the addition of metal ions to EDTA-treated protease did not significantly change enzyme activity, indicating that proteolysis is not metal ion-dependent. The purified enzyme was completely inactivated by the aspartic protease inhibitor Pepstatin A.

Conclusion: Based on the observed enzyme activity, inhibition profile with Pepstatin A, and sequence similarity to other rhizopuspepsins, we have classified this enzyme as an aspartic protease.
\end{abstract}

(C) 2014 Pontificia Universidad Católica de Valparaíso. Production and hosting by Elsevier B.V. All rights reserved.

\section{Introduction}

Proteases, also referred to as peptidases or proteinases, are a large category of enzymes that catalyze the hydrolysis of peptide bonds. Proteases that cleave peptide bonds at the $\mathrm{N}$ or $\mathrm{C}$ termini of polypeptide chains are called exopeptidases and those that cleave peptide bonds within the polypeptide chain are classified as endopeptidases [1]. Proteases can be classified as aspartic, cysteine, glutamic, serine, and threonine proteases, depending upon the amino acids present in the

\footnotetext{
* Corresponding author.

E-mail address: chkao@hk.edu.tw (C.-H. Kao).

Peer review under responsibility of Pontificia Universidad Católica de Valparaíso.
}

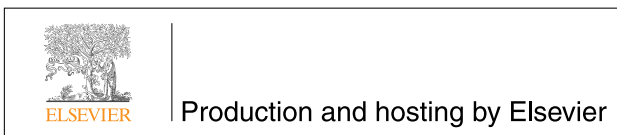

1 These authors contributed equally. active site, or as metalloproteases if a metal ion is required for catalytic activity [2]. Proteases occur naturally in all organisms and are involved in many physiological processes, including the production of nutrients for cell growth and proliferation [3], protein degradation [4], and as regulatory components for diverse physiological functions $[5,6]$. Microbial sourced proteases are valuable commercial enzymes that account for approximately $60 \%$ of the total worldwide sales of industrial enzymes [7]; they are used in the food, pharmaceutical, detergent, and biotechnology industries $[1,8,9,10,11]$.

Aspartic proteases (EC 3.4.23), also known as acidic proteases, are a subfamily of endopeptidases that have been isolated from diverse sources, including viruses, bacteria, fungi, plants, and animals $[12,13,14]$. Several fungal aspartic proteases have been purified and characterized as rennin-like and pepsin-like enzymes [7]. The renninlike enzymes are produced by Endothia parasitica (endothiapepsin, EC 3.4.23.22), Mucor, and Rhizomucor species (mucorpepsin, EC 3.4.23.23) [10]. The pepsin-like enzymes include aspergillopepsin (aspergillopepsin I, EC 3.4.23.18) from Aspergillus species [15] and rhizopuspepsin (EC 3.4.23.21) from Rhizopus species [16]. These 
enzymes have molecular weights in a range of 30-45 kDa and contain one or two conserved aspartic acid residues at the active site $[2,17]$. Aspartic proteases are optimally active at acidic $\mathrm{pH}(\mathrm{pH} 3-5)$ and are specifically inhibited by Pepstatin A $[12,15,16]$. Because of their high activity and stability in acidic environments, aspartic proteases are useful reagents in the food processing industry. For example, aspartic proteases are used as milk-coagulating enzymes for the manufacture of cheese [10] and as additives to improve food flavor and texture [18].

Aspartic proteases form the dominant class of Rhizopus secreted proteases, known as rhizopuspepsins $[3,19]$. Species from which rhizopuspepsins have been isolated and biochemically characterized include Rhizopus chinensis [20], Rhizopus microsporus [21], Rhizopus hangchow [22], Rhizopus oryzae MTCC 3690 [16], and R. oryzae NBRC 4749 [23]. A suitable milk-coagulating enzyme must have high specific caseinolytic activity; however, many reported activity levels are poor. A neutral protease preparation derived from $R$. oryzae, Peptidase $\mathrm{R}$, is used in commercial food processing to improve taste and nutritional content. Here we describe the purification and characterization of a Peptidase R-derived protein with high caseinolytic activity and an inhibition profile consistent with that of an aspartic acid protease.

\section{Materials and methods}

\subsection{Chemicals}

Peptidase $\mathrm{R}$ was purchased from Amano Enzyme Inc. (Nagoya, Japan). Casein, Pepstatin A, phenylmethylsulfonyl fluoride (PMSF), Pefabloc SC, N-ethylmaleimide, iodoacetic acid, $\beta$-mercaptoethanol, and dithiothreitol were purchased from Sigma-Aldrich (St. Louis, MO). All other chemicals and solvents were of analytical grade and were purchased from Merck (Darmstadt, Germany) and Sigma-Aldrich.

\subsection{Protein purification}

All purification steps were performed at $4^{\circ} \mathrm{C}$ on an AKTA Purifier 10 system (GE Healthcare Biosciences, Uppsala, Sweden). Peptidase R (500 mg) was dissolved in $50 \mathrm{~mL}$ of $50 \mathrm{mM}$ sodium phosphate buffer, $\mathrm{pH} 7.0$, and filtered through a 25-mm Millex-HA filter (Millipore, Bedford, MA) with a $0.45-\mu \mathrm{m}$ pore size. The enzyme solution was loaded onto a HiLoad 26/10 Q Sepharose High-Performance column (GE Healthcare Biosciences) equilibrated with $50 \mathrm{mM}$ sodium phosphate buffer, $\mathrm{pH}$ 7.0. Fractions were eluted at a flow rate of $10 \mathrm{~mL} / \mathrm{min}$ using equilibration buffer with a $\mathrm{NaCl}$ stepwise gradient of $0-0.17 \mathrm{M}$ for $180 \mathrm{~mL}, 0.17-0.30 \mathrm{M}$ for $480 \mathrm{~mL}$, and $0.30-1.0 \mathrm{M}$ for $300 \mathrm{~mL}$. Fractions were detected by UV absorbance at $280 \mathrm{~nm}$ for collection. Aspartic protease activity in the collected fractions was measured as described in Section 2.5. Aspartic protease containing fractions were pooled, and ammonium sulfate was added to $50 \%(\mathrm{v} / \mathrm{v})$ final concentration to precipitate contaminating proteins. Insoluble protein was removed by centrifugation at $12,000 \mathrm{rpm}$ and $4^{\circ} \mathrm{C}$ for $10 \mathrm{~min}$. The supernatant was applied to a HiTrap Phenyl Sepharose column (GE Healthcare Biosciences) equilibrated with $50 \mathrm{mM}$ sodium phosphate buffer, $\mathrm{pH}$ 7.0. Aspartic protease was eluted at a flow rate of $1 \mathrm{~mL} / \mathrm{min}$ using equilibration buffer with a linear descending gradient of ammonium sulfate from $100 \%$ (saturated solution) to $0 \%$. Fractions exhibiting aspartic protease activity were combined and dialyzed against $50 \mathrm{mM}$ glycine- $\mathrm{HCl}$ buffer, $\mathrm{pH} 3.4$, for storage. The purified protein was concentrated by ultrafiltration using an Amicon Centrifugal Filter Device (10 kDa cutoff; Millipore), and stored at $4^{\circ} \mathrm{C}$.

\subsection{Molecular weight determination and protein quantification}

Protein homogeneity and molecular weight were determined by sodium dodecyl sulfate-polyacrylamide gel electrophoresis (SDSPAGE) in $5 \%$ stacking and $12 \%$ separating gels, using broad-range protein markers (6.5-200 kDa; Bio-Rad Laboratories, Richmond, CA) as size standards. The proteins in the gel were stained with Bio-safe Coomassie Blue (Bio-Rad Laboratories). Protein molecular weight was determined using TotalLab software (Nonlinear, Durham, NC) according to the manufacturer's instructions. Protein concentrations were quantified using a Bio-Rad Protein Assay Kit with bovine serum albumin as the standard.

\subsection{N-terminal amino acid sequencing}

Purified enzyme was separated by SDS-PAGE gel and transferred by electroblotting to a polyvinylidene fluoride (PVDF) membrane (Millipore) in $10 \mathrm{mM}$ 3-(cyclohexylamino)-1-propanesulfonic acid buffer, pH 11, containing $10 \%$ methanol. The transferred protein was stained with Coomassie Blue R-250 and the band containing purified protein was excised from the membrane for N-terminal amino acid sequencing by Edman degradation using an ABI Procise 494 protein sequencer (Applied Biosystems, Foster City, CA). Comparison of the sequence with similar protease-encoding sequences in GenBank was performed using the Basic Local Alignment Search Tool (BLAST) on the National Center for Biotechnology Information (NCBI) website (http://blast.ncbi.nlm.nih.gov/Blast.cgi). Multiple sequence alignment and identities (\%) were performed using Clustal Omega on the European Bioinformatics Institute (EMBL-EBI) website (http://www.ebi.ac.uk/Tools/msa/clustalo/).

\subsection{Enzyme activity assay}

Proteolytic activity was measured using casein as a substrate. The reaction mixture, containing $50 \mu \mathrm{L}$ of $2 \%(\mathrm{w} / \mathrm{v})$ casein solution, $190 \mu \mathrm{L}$ of $50 \mathrm{mM}$ glycine- $\mathrm{HCl}$ buffer, $\mathrm{pH} 3.4$, and $10 \mu \mathrm{L}$ of the appropriate concentration of purified enzyme, was incubated at $35^{\circ} \mathrm{C}$ for $30 \mathrm{~min}$. The reaction was terminated by adding a $250 \mu \mathrm{L}$ of $10 \%(\mathrm{w} / \mathrm{v})$ trichloroacetic acid. Precipitated protein was removed by centrifugation at $12,000 \mathrm{rpm}$ and $4^{\circ} \mathrm{C}$ for $10 \mathrm{~min}$. The absorbance of the supernatant at $280 \mathrm{~nm}$ was measured using a Hitachi U3000 spectrophotometer (Hitachi, Tokyo, Japan). One unit (U) of enzyme activity was defined as the amount of enzyme required to increase the absorbance at $280 \mathrm{~nm}$ by $0.001 \mathrm{AU}$ per minute under the aforementioned assay conditions [15].

\subsection{Enzyme characterization for $\mathrm{pH}$ and temperature optima}

The optimal $\mathrm{pH}$ for purified aspartic protease was determined by measuring activity at $35^{\circ} \mathrm{C}$ for $30 \mathrm{~min}$ over the $\mathrm{pH}$ range $2.2-4.0$ using $50 \mathrm{mM}$ glycine- $\mathrm{HCl}$ ( $\mathrm{pH} 2.2-3.6)$ and $50 \mathrm{mM}$ sodium citrate $(\mathrm{pH} 2.6-$ 4.0 ) as assay buffers. The optimal temperature for protease activity was determined through assays performed using temperatures of 15$85^{\circ} \mathrm{C}$ for the $30 \mathrm{~min}$ incubation step in $50 \mathrm{mM}$ glycine- $\mathrm{HCl}$ buffer, $\mathrm{pH}$ 3.4. The maximum observed activity under any of the documented reaction conditions was defined as $100 \%$ and the relative activities were calculated as a fraction of this value.

\subsection{Thermostability}

Thermostability of the aspartic protease was determined by incubating the purified enzyme for $65 \mathrm{~min}$ in $50 \mathrm{mM}$ glycine- $\mathrm{HCl}$ buffer, $\mathrm{pH}$ 3.4, at $35^{\circ} \mathrm{C}$ and $45^{\circ} \mathrm{C}$. At defined time intervals, the enzyme solutions were cooled in ice and residual activity was assayed under standard enzyme assay conditions. The relative residual activity was expressed as a percentage of the observed activity for the unheated enzyme.

\subsection{Effect of chemical reagents and metal ions on enzyme activity}

To determine the effects of protease inhibitors and cysteine protease activators on enzyme activity, purified enzyme was incubated with each reagent in $50 \mathrm{mM}$ glycine- $\mathrm{HCl}$ buffer, $\mathrm{pH} \mathrm{3.4,} \mathrm{at} 35^{\circ} \mathrm{C}$ for $30 \mathrm{~min}$, followed by measuring its activity under the standard assay conditions 
described above. The enzyme was assayed for inhibition by the serine protease inhibitors PMSF (0.1 mM and $1 \mathrm{mM})$ and Pefabloc SC $(1 \mathrm{mM})$, the cysteine protease inhibitors $\mathrm{N}$-ethylmaleimide $(1 \mathrm{mM})$, and iodoacetic acid $(1 \mathrm{mM})$, and the aspartic protease inhibitor pepstatin $\mathrm{A}(1 \mu \mathrm{M})$. Assays were also performed on the enzyme with $\beta$-mercaptoethanol (1 $\mathrm{mM})$ and dithriothreitol $(1 \mathrm{mM})$, which are known to enhance cysteine protease activity.

To determine whether the protease is metal-dependent, an assay was performed on the purified protein following incubation with the chelator ethylenediamine tetraacetic acid (EDTA). Specifically, purified enzyme was incubated at $35^{\circ} \mathrm{C}$ for $30 \mathrm{~min}$ in $50 \mathrm{mM}$ glycine- $\mathrm{HCl}$ buffer, pH 3.4, with 10 mM EDTA. EDTA was removed by centrifugal ultrafiltration using an Amicon Centrifugal Filter Device (10 kDa cutoff; Millipore) prior to spectrophotometrically assaying for activity. The effect of added divalent metals on EDTA-treated enzyme was determined by incubating the enzyme following chelator removal with an aqueous metal chloride solution at a final concentration of $1 \mathrm{mM}$ for $30 \mathrm{~min}$. The enzyme was assayed in the presence of $\mathrm{CaCl}_{2}, \mathrm{ZnCl}_{2}, \mathrm{NiCl}_{2}, \mathrm{CuCl}_{2}, \mathrm{MnCl}_{2}$, and $\mathrm{CoCl}_{2}$. Relative activity is expressed as a percentage of un-treated enzyme activity.

\section{Results and discussion}

\subsection{Purification of aspartic protease}

A crude enzyme solution of Peptidase R exhibiting aspartic protease activity $\left(17 \times 10^{3} \mathrm{U} / \mathrm{mg}\right)$ was separated by chromatography using a HiLoad 26/10 Q Sepharose High-Performance column and eluted with a stepwise $\mathrm{NaCl}$ gradient. The chromatographic profile is shown in Fig. 1a. There are two major protein peaks; the one eluting at $0.17-$ $0.20 \mathrm{M} \mathrm{NaCl}$ contained active protein. The specific activity of the pooled active fractions was $36.7 \times 10^{3} \mathrm{U} / \mathrm{mg}$, representing a $90.6 \%$ yield of the original enzyme activity. Active fractions were further purified by hydrophobic interaction chromatography on a HiTrap Phenyl Sepharose column where Fractions 9-15 contained target enzyme activity (Fig. 1b) and were pooled to comprise the final sample of purified protease. A summary of the purification steps for Peptidase R-derived aspartic protease is shown in Table 1. After two column chromatography purification steps, the enzyme was purified 3.4-fold from a crude Peptidase R, with a final yield of $58.8 \%$ and an observed specific activity of $57.5 \times 10^{3} \mathrm{U} / \mathrm{mg}$. Aspartic proteases purified from Aspergillus oryzae MTCC 5341 [15] and Aspergillus niger BCRC 32720 [18] showed high proteolytic activity with a specific activity of about $43.6 \times 10^{3} \mathrm{U} / \mathrm{mg}$ and $23.3 \times 10^{3} \mathrm{U} / \mathrm{mg}$, respectively. The activity of the aspartic protease purified here was one of the highest reported, and may be useful as a digestive aid.

Enzyme purity was confirmed by SDS-PAGE. The purified protein migrated as a single band with an apparent molecular weight of $\sim 39 \mathrm{kDa}$ (Fig. 2). The molecular weight of the purified enzyme is higher than reported for rhizopuspepsins from $R$. oryzae MTCC 3690 (34 kDa) [16], R. oryzae NBRC 4749 (34 kDa) [23], and R. microsporus (34.5 kDa) [21]. These results suggest that the purified protease from Peptidase $R$ is a distinct, previously unreported rhizopuspepsin.

\subsection{N-terminal amino acid sequence analysis}

The N-terminal amino acid sequence of the purified protease was identified as Ser-Gly-Ser-Gly-Val-Val-Pro-Met-Thr-Asp-Tyr-Glu-Tyr-

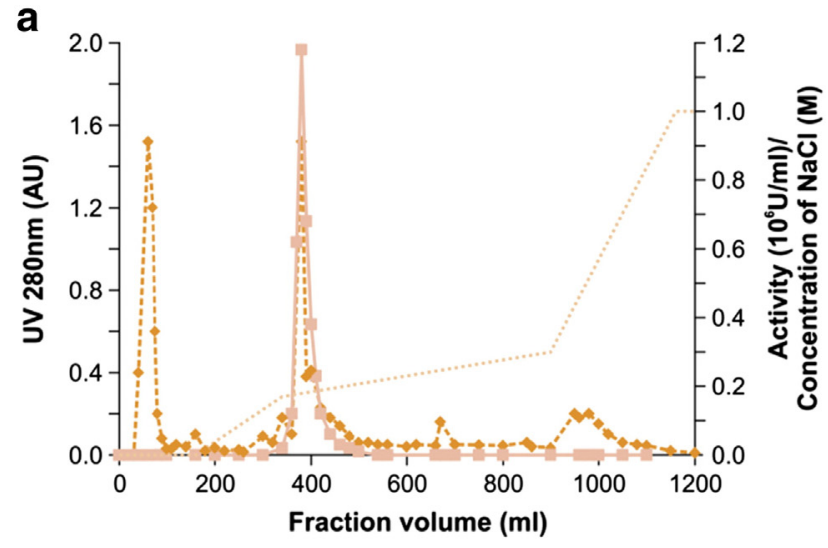

$-\uparrow$ Absorbance at $280 \mathrm{~nm}-$ Activity $\cdots$ Concentration of $\mathrm{NaCl}$

\section{b}

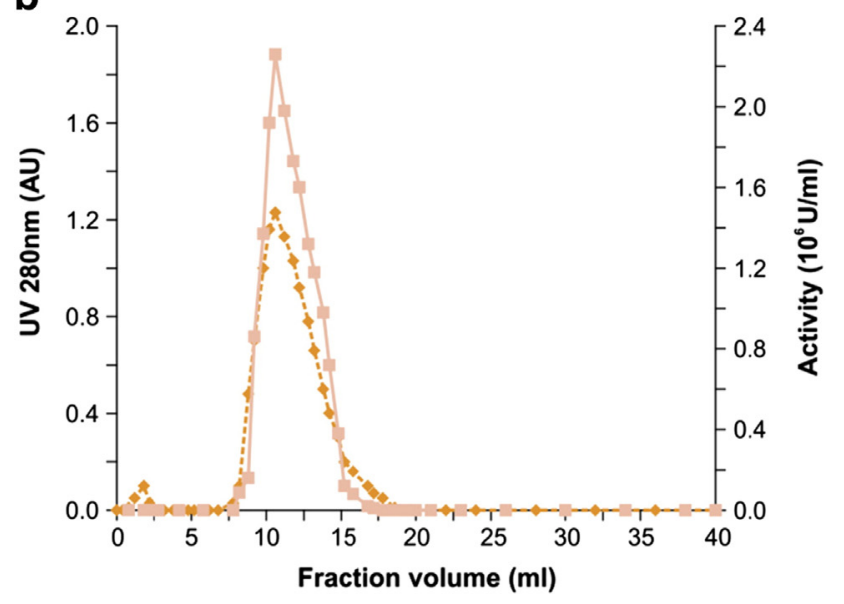

Fig. 1. Chromatographic purification of an aspartic protease from $R$. oryzae crude enzyme preparation. (a) Anion exchange chromatography using a HiLoad 26/10 Q Sepharose High-Performance column (b) hydrophobic interaction chromatography using a HiTrap Phenyl Sepharose column. Purification conditions are described in Materials and methods.

Asp-Ile-Glu-Tyr. Homology search and multiple sequence alignment results are shown in Fig. 3. The N-terminal amino acid sequence of the purified enzyme shows $75,71,69$, and $63 \%$ identity to rhizopuspepsins from $R$. oryzae (GenBank accession no. ACL68093.1), R. microsporus var. chinensis (GenBank accession no. AAA33880.1), $R$. niveus (GenBank accession no. AAA33882.1), and R. oryzae NBRC 4749 (GenBank accession no. ACL68087.1), respectively. It was also 71\% identical to syncephapepsin from Syncephalastrum racemosum (GenBank accession no. AAC69517.1) and was only 31\% identical to aspergillopepsin I from A. niger (GenBank accession no. XP_ 001401093.1). The sequence homology with rennin-like enzymes endothiapepsin and mucorpepsin was low (data not included in Fig. 3). For protein identification, the $\mathrm{N}$-terminal sequence was also used to search the genome database for R. oryzae RA 99-880 (http://www.broadinstitute.org/annotation/genome/rhizopus_oryzae/Blast.html), but a significantly similar sequence was not identified. The N-terminal

Table 1

Purification of an aspartic protease from a $R$. oryzae crude enzyme preparation.

\begin{tabular}{|c|c|c|c|c|c|}
\hline Purification step & $\begin{array}{l}\text { Total protein } \\
(\mathrm{mg})\end{array}$ & $\begin{array}{l}\text { Total activity } \\
\left(10^{6} \mathrm{U}\right)\end{array}$ & $\begin{array}{l}\text { Specific activity } \\
\left(10^{3} \mathrm{U} / \mathrm{mg}\right)\end{array}$ & Fold purification & $\begin{array}{l}\text { Yield } \\
(\%)\end{array}$ \\
\hline Crude enzyme & 500 & 8.5 & 17.0 & 1 & 100 \\
\hline Q Sepharose & 210 & 7.7 & 36.7 & 2.2 & 90.6 \\
\hline Phenyl Sepharose & 87 & 5.0 & 57.5 & 3.4 & 58.8 \\
\hline
\end{tabular}




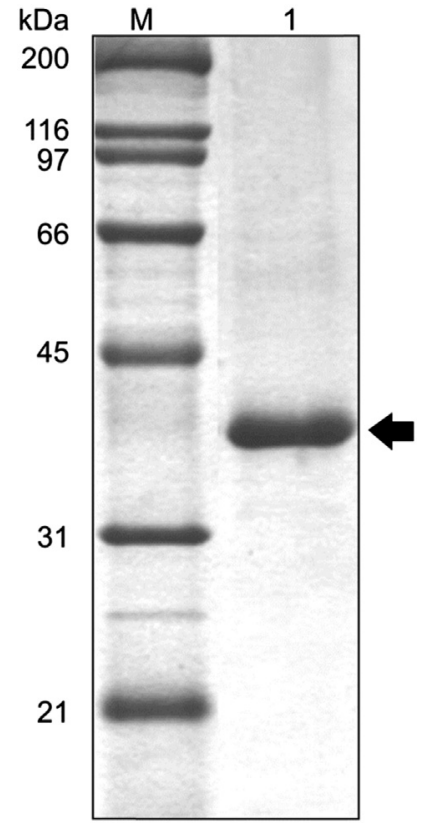

Fig. 2. SDS-PAGE profile of purified aspartic protease. Lane $M$, molecular weight markers; lane 1, purified aspartic protease. The arrow indicates the band corresponding to the purified aspartic protease (approximate molecular weight, $39 \mathrm{kDa}$ ).

amino acid sequence of the purified enzyme showed high homology to those of rhizopuspepsins, indicating that the purified enzyme possesses aspartic protease activity.

\subsection{Effects of $\mathrm{pH}$ and temperature on enzyme activity and stability}

Protease activity of the purified enzyme was surveyed across the $\mathrm{pH}$ range $2.2-4$ using casein as a substrate at an assay temperature of $35^{\circ} \mathrm{C}$. The $\mathrm{pH}$ profile of the purified aspartic protease is shown in Fig. 4a. The enzyme was most active between $\mathrm{pH}$ values 3.0-3.6 with maximal activity at $\mathrm{pH}$ 3.4. Protease activity decreased significantly below $\mathrm{pH} 3.0$ and was approximately $45 \%$ of the maximal activity when assayed at pH 2.2 in glycine- $\mathrm{HCl}$ buffer. Enzyme activity was slightly reduced at $\mathrm{pH} 4.0$ in sodium citrate buffer and was not detected at pH 7.0 (data not shown). Similar pH optima for protease activities have been reported from $R$. oryzae NBRC 4749, pH 3.0 [23]; R. hangchow, pH 3.0 [22]; $R$. chinensis, $\mathrm{pH} 3.1$ [20]; A. niger I1, pH 3.0 [24]; and A. oryzae MTCC 5341, pH 3.2 [15]. The pH optima in the same range have also been reported for mucorpepsins from several Mucor species [10]. In contrast, the $R$. oryzae MTCC 3690 enzyme

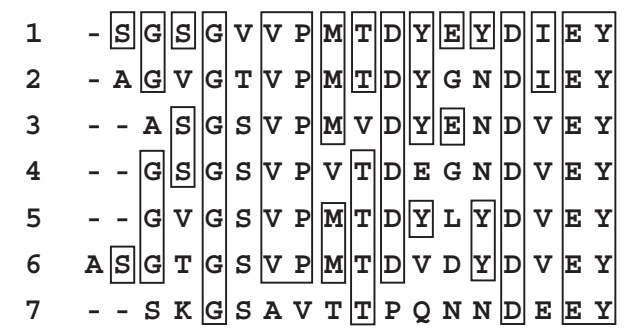

Fig. 3. Multiple sequence alignment of N-terminal amino acid sequences of the purified and other fungal aspartic proteases. (1) aspartic protease purified from Peptidase $\mathrm{R}$; (2) rhizopuspepsin from R. microsporus var. chinensis (GenBank accession no. AAA33880.1); (3) rhizopuspepsin from $R$. niveus (GenBank accession no. AAA33882.1); (4) rhizopuspepsin from $R$. oryzae NBRC 4749 (GenBank accession no. ACL68087.1); (5) rhizopuspepsin from $R$. oryzae (GenBank accession no. ACL68093.1); (6) syncephapepsin from S. racemosum (GenBank accession no. AAC69517.1); (7) aspergillopepsin from A. niger (GenBank accession no. XP_001401093.1). Identical residues are boxed.
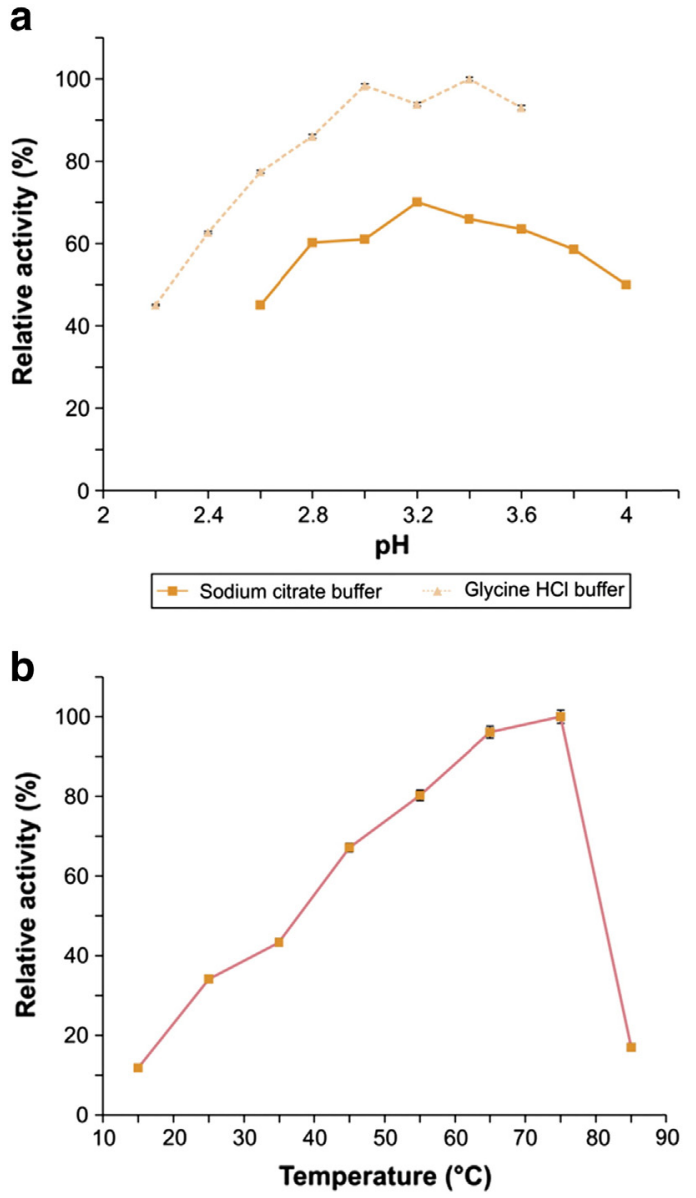

Fig. 4. Determination of the optimal $\mathrm{pH}$ and temperature for the purified aspartic protease. (a) The effect of $\mathrm{pH}$ on the activity of purified protease was determined at $35^{\circ} \mathrm{C}$ for a 30 min incubation, as described in Materials and methods, with either $50 \mathrm{mM}$ glycine- $\mathrm{HCl}$, pH 2.2-3.6 ( $\mathbf{\Delta}$ ) or $50 \mathrm{mM}$ sodium citrate, pH 2.6-4.0 (ם) buffer. (b) Temperature optima were determined in $50 \mathrm{mM}$ glycine- $\mathrm{HCl}$ buffer, $\mathrm{pH} 3.4$ at various temperatures for $30 \mathrm{~min}$. The data points shown are the means for three independent experiments, and the highest observed activity was defined as $100 \%$. The error bars indicate standard deviations.

exhibits optimal activity at pH 5.5 [16] and the enzymes from A. niger BCRC32720 [18] and R. microsporus exhibit optimal activity at $\mathrm{pH} 2.5$ [21]. Most fungal aspartic proteases show maximal activity at $\mathrm{pH} 3-4$, because the pair of aspartic acid residues in the active site must react in ionized and unionized form for catalytic activity [7]. The pH optimum might indicate a similar reaction mechanism between the purified enzyme and aspartic proteases.

During the $\mathrm{pH}$ optimization study, we observed that the enzyme activity was higher across $\mathrm{pH}$ values $2.6-3.6$ in glycine- $\mathrm{HCl}$ versus sodium citrate buffer. This phenomenon was also observed in rhizopuspepsin from $R$. oryzae NBRC 4749, in which enzyme activity is higher at pH 3.0 in glycine- $\mathrm{HCl}$ buffer than in citrate phosphate buffer [23]. Glycine is a common bulking agent in pharmaceutical protein formulations and is used to stabilize the protein during freeze-thawing solution [25]. Glycine has also been used to improve the stability of alkaline proteases at high temperature and in detergents [26]. We suggest that glycine is protonated at low $\mathrm{pH}$ in the glycine- $\mathrm{HCl}$ buffer; this might prevent protein aggregation in the buffer system, leading to higher proteolytic activity. The effects of glycine on the aggregation and stability of the purified aspartic protease will be examined in the future.

As shown in Fig. 4b, hydrolytic activity of the purified protease increased with increasing temperature, reaching a maximum at $75^{\circ} \mathrm{C}$, which is higher than those previously reported for rhizopuspepsins from $R$. oryzae NBRC $4749\left(50^{\circ} \mathrm{C}\right)[23]$ and $R$. oryzae MTCC $3690\left(60^{\circ} \mathrm{C}\right)$ 
[16]. The thermostability profile of the purified protease is shown in Fig. 5 . At $35^{\circ} \mathrm{C}$, the enzyme retained full activity after $1 \mathrm{~h}$ of incubation. At $45^{\circ} \mathrm{C}$, enzyme activity decreased with increasing incubation time; the observed half-life for the protease was approximately $30 \mathrm{~min}$ at $45^{\circ} \mathrm{C}$. Rhizopuspepsin from $R$. oryzae MTCC 3690 has a half-life of approximately $20 \mathrm{~min}$ at $60^{\circ} \mathrm{C}$ and retains full activity after

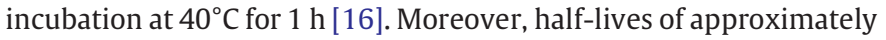
$3.5 \mathrm{~h}$ and $10 \mathrm{~min}$ at $40^{\circ} \mathrm{C}$ and $60^{\circ} \mathrm{C}$, respectively, were reported for rhizopuspepsin 6 from $R$. oryzae NBRC 4749 [23]. These results suggest that aspartic proteases from Rhizopus species seem to be stable at temperatures below $40^{\circ} \mathrm{C}$ and prone to inactivation above this temperature.

\subsection{Effects of inhibitors and metal ions}

To characterize the purified protease, the effects of various inhibitors on enzyme activity were examined. The purified protease was strongly inhibited by Pepstatin A, a hexapeptide inhibitor that specifically and irreversibly binds aspartate within the aspartic protease active site, with complete inactivation occurring at an inhibitor concentration of $1 \mu \mathrm{M}$ (Table 2). In contrast, serine protease inhibitors (PMSF and Pefabloc SC) and cysteine protease inhibitors ( $N$-ethylmaleimide and iodoacetic acid) did not inhibit enzyme activity even at $1 \mathrm{mM}$ (data not shown). The cysteine protease activators dithiothreitol ( $1 \mathrm{mM}$ ) and $\beta$-mercaptoethanol $(1 \mathrm{mM})$ did not increase protease activity (data not shown). Strong inhibition by the aspartic protease inhibitor, Pepstatin A, suggests that the purified protein may be classified as an aspartic protease.

The effects of EDTA and metal ions on EDTA-treated enzyme were examined at $\mathrm{pH} 3.4$ and $35^{\circ} \mathrm{C}$ using casein as substrate (Table 2). The chelating agent EDTA ( $10 \mathrm{mM}$ ) had no effect on enzyme activity, suggesting that it is not a metalloprotease. The addition of $1 \mathrm{mM}$ $\mathrm{Ca}^{2+}$ had no effect on proteolytic activity, while the addition of $1 \mathrm{mM} \mathrm{Zn}^{2+}, \mathrm{Ni}^{2+}, \mathrm{Cu}^{2+}, \mathrm{Mn}^{2+}$, and $\mathrm{Co}^{2+}$ slightly reduced enzyme activity. These results indicate that the activity of the purified enzyme is not metallo-dependent. Metal ions have varying effects on the activity of aspartic proteases from different fungi. Rhizopuspepsin from $R$. chinensis is significantly inhibited by $\mathrm{Fe}^{3+}$, while no inhibitory

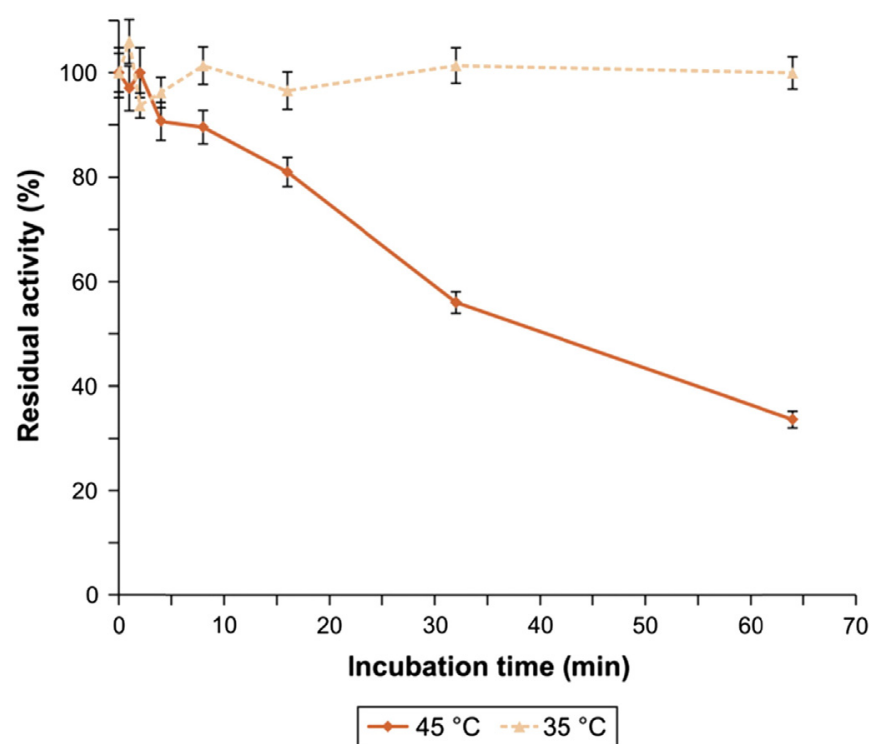

Fig. 5. Determination of thermostability of the purified aspartic protease. Thermostability was determined through assays of purified enzyme in $50 \mathrm{mM}$ glycine- $\mathrm{HCl}$ buffer ( $\mathrm{pH} 3.4$ ) incubated at $35^{\circ} \mathrm{C}(\boldsymbol{\Delta})$ or $45^{\circ} \mathrm{C}(\bullet)$ and enzyme activity was assayed under standard conditions. The residual activity is expressed as the percentage compared to the activity of un-incubated enzyme. The data points shown are the means of three independent experiments and the error bars indicate standard deviations.
Table 2

Effects of protease inhibitors and various metal ions on purified enzyme activity.

\begin{tabular}{lll}
\hline Compound & Concentration & Relative activity (\%) \\
\hline None & 0 & $100.0 \pm 3.6$ \\
Pepstatin A & $1 \mu \mathrm{M}$ & 0 \\
EDTA & $10 \mathrm{mM}$ & $101.4 \pm 3.8$ \\
$\mathrm{CaCl}_{2}$ & $1 \mathrm{mM}$ & $98.6 \pm 3.5$ \\
$\mathrm{ZnCl}_{2}$ & $1 \mathrm{mM}$ & $87.8 \pm 3.2$ \\
$\mathrm{NiCl}_{2}$ & $1 \mathrm{mM}$ & $84.2 \pm 2.9$ \\
$\mathrm{CuCl}_{2}$ & $1 \mathrm{mM}$ & $87.2 \pm 2.6$ \\
$\mathrm{MnCl}_{2}$ & $1 \mathrm{mM}$ & $84.7 \pm 2.3$ \\
$\mathrm{CoCl}_{2}$ & $1 \mathrm{mM}$ & $88.3 \pm 2.7$ \\
\hline
\end{tabular}

a Enzyme activity assayed in the absence of metal ions and inhibitors was defined as $100 \%$ activity.

effect is observed with $\mathrm{Cu}^{2+}, \mathrm{Hg}^{2+}, \mathrm{Fe}^{2+}$, and $\mathrm{Pb}^{2+}[20] . \mathrm{Fe}^{2+}$ strongly activates and $\mathrm{Fe}^{3+}, \mathrm{Cr}^{3+}, \mathrm{Sb}^{3+}, \mathrm{Pb}^{2+}, \mathrm{Sn}^{2+}, \mathrm{Sr}^{2+}$, and $\mathrm{Ag}^{+}$strongly inhibits the enzyme from $A$. niger BCRC 32720 [18]. $\mathrm{Cu}^{2+}$ strongly inhibits the enzyme from A. niger I1 [24]. $\mathrm{Ca}^{2+}$ is a potent activator that combines with para-К-casein to form firm clots during milk clotting [10]. The proteolytic activity of purified aspartic protease was not inhibited by $\mathrm{Ca}^{2+}$, supporting its potential utility in food processing.

\section{Concluding remarks}

An aspartic protease was purified to homogeneity from a commercial Peptidase R preparation by liquid chromatography using a strong anion exchange column followed by a hydrophobic interaction chromatography step, resulting in a 3.4-fold increase in specific activity and a yield of $58.8 \%$. The molecular weight of the purified enzyme was determined to be approximately $39 \mathrm{kDa}$ by SDS-PAGE. The purified enzyme appears to be an aspartic protease, based on observed inhibition in the presence of Pepstatin A. The enzyme was optimally active at $\mathrm{pH} 3.4$ and stable at $35^{\circ} \mathrm{C}$, appropriate for biotechnological applications and food processing. Genetic and protein structural analyses are in progress to elucidate the biochemical properties of and potential industrial applications for this enzyme.

\section{Conflict of interest}

The authors declare that they have no conflict of interets.

\section{Acknowledgments}

This work was supported by grant nos. 98-2313-B-241-006-MY3 and 101-2313-B-241-001-MY3 from the National Science Council of Taiwan.

\section{References}

[1] López-Otín C, Bond JS. Proteases: Multifunctional enzymes in life and disease. J Biol Chem 2008;283:30433-7. http://dx.doi.org/10.1074/jbc.R800035200.

[2] Sumantha A, Larroche C, Pandey A. Microbiology and industrial biotechnology of food-grade proteases: a perspective. Food Technol Biotechnol 2006;44:211-20.

[3] Lin JS, Lee SK, Chen Y, Lin WD, Kao CH. Purification and characterization of a novel extracellular tripeptidyl peptidase from Rhizopus oligosporus. J Agric Food Chem 2011;59:11330-7. http://dx.doi.org/10.1021/jf201879e.

[4] Ciechanover A. Proteolysis: From the lysosome to ubiquitin and the proteasome. Nat Rev Mol Cell Biol 2005;6:79-87. http://dx.doi.org/10.1038/nrm1552.

[5] Ehrmann M, Clausen T. Proteolysis as a regulatory mechanism. Annu Rev Genet 2004;38:709-24. http://dx.doi.org/10.1146/annurev.genet.38.072902.093416.

[6] Oikonomopoulou K, Hansen KK, Saifeddine M, Vergnolle N, Tea I, Diamandis EP, et al. Proteinase-mediated cell signalling: Targeting proteinase-activated receptors (PARs) by kallikreins and more. Biol Chem 2006;387:677-85. http://dx.doi.org/ 10.1515/BC.2006.086.

[7] Rao MB, Tanksale AM, Ghatge MS, Deshpande VV. Molecular and biotechnological aspects of microbial proteases. Microbiol Mol Biol Rev 1998;62:597-635.

[8] Najafi MF, Deobagkar D, Deobagkar D. Potential application of protease isolated from Pseudomonas aeruginosa PD100. Electron J Biotechnol 2005;8.

[9] Sabotič J, Kos J. Microbial and fungal protease inhibitors-current and potential applications. Appl Microbiol Biotechnol 2012;93:1351-75. http://dx.doi.org/10.1007/ s00253-011-3834-X. 
[10] Yegin S, Fernandez-Lahore M, Gama-Salgado AJ, Guvenc U, Goksungur Y, Tari C. Aspartic proteinases from Mucor spp. in cheese manufacturing. Appl Microbiol Biotechnol 2011;89:949-60. http://dx.doi.org/10.1007/s00253-010-3020-6.

[11] Zhao G, Zhou A, Lu G, Meng M, Sun M, Bai Y. Identification and characterization of Toxoplasma gondii aspartic protease 1 as a novel vaccine candidate against toxoplasmosis. Parasites Vectors 2013;6:175. http://dx.doi.org/10.1186/1756-3305-6-175.

[12] Chen J, Ouyang Y, Wang L, Xie W, Zhang Q. Aspartic proteases gene family in rice: Gene structure and expression, predicted protein features and phylogenetic relation. Gene 2009;442:108-18. http://dx.doi.org/10.1016/j.gene.2009.04.021.

[13] Hartl MJ, Schweimer K, Reger MH, Schwarzinger S, Bodem J, Rösch P, et al. Formation of transient dimers by a retroviral protease. Biochem J 2010;427:197-203. http://dx.doi.org/10.1042/BJ20091451.

[14] Radisky ES. Cathepsin D: Regulation in mammary gland remodeling, misregulation in breast cancer. Cancer Biol Ther 2010;10:467-70. http://dx.doi.org/10.4161/ cbt.10.5.12855.

[15] Vishwanatha KS, Appu Rao AG, Singh SA. Characterisation of acid protease expressed from Aspergillus oryzae MTCC 5341. Food Chem 2009;114:402-7. http://dx.doi.org/ 10.1016/j.foodchem.2008.09.070.

[16] Kumar S, Sharma NS, Saharan MR, Singh R. Extracellular acid protease from Rhizopus oryzae: purification and characterization. Process Biochem 2005;40:1701-5. http://dx.doi.org/10.1016/j.procbio.2004.06.047.

[17] Milisavljevic MD, Timotijevic GS, Radovic SR, Konstantinovic MM, Maksimovic VR. Two types of aspartic proteinases from buckwheat seed-gene structure and expression analysis. J Plant Physiol 2008;165:983-90. http://dx.doi.org/10.1016/ j.jplph.2007.03.016.

[18] Yin LJ, Hsu TH, Jiang ST. Characterization of acidic protease from Aspergillus niger BCRC 32720. J Agric Food Chem 2013;61:662-6. http://dx.doi.org/ $10.1021 / \mathrm{jf} 3041726$.
[19] Heskamp ML, Barz W. Expression of proteases by Rhizopus species during Tempeh fermentation of soybeans. Food/Nahrung 1998;42:23-8. http://dx.doi.org/10.1002/ (SICI)1521-3803(199802)42:01<23::AID-FOOD23>3.0.CO;2-3.

[20] Fukumoto J, Daisuke T, Yamamoto T. Studies on mold protease. Part I: Purification, crystallization and some enzymatic properties of acid protease of Rhizopus chinensis. Agric Biol Chem 1967;31:710-7.

[21] Schoen C, Reichard U, Monod M, Kratzin H, Rüchel R. Molecular cloning of an extracellular aspartic proteinase from Rhizopus microsporus and evidence for its expression during infection. Med Mycol 2002;40:61-71. http://dx.doi.org/10.1080/ 714031076.

[22] Ichishima E, Ojima M, Yamagata Y, Hanzawa S, Nakamura T. Molecular and enzymatic properties of an aspartic proteinase from Rhizopus hangchow. Phytochemistry 1995;38:27-30. http://dx.doi.org/10.1016/0031-9422(94)00552-5.

[23] Chen CC, Cho YC, Lai CC, Hsu WH. Purification and characterization of a new rhizopuspepsin from Rhizopus oryzae NBRC 4749. J Agric Food Chem 2009;57:6742-7. http://dx.doi.org/10.1021/jf8040337.

[24] Siala R, Sellami-Kamoun A, Hajji M, Abid I, Gharsallah N, Nasri M. Extracellular acid protease from Aspergillus niger I1: Purification and characterization. Afr J Biotechnol 2009;8:4582-9.

[25] Pikal-Cleland KA, Cleland JL, Anchordoquy TJ, Carpenter JF. Effect of glycine on pH changes and protein stability during freeze-thawing in phosphate buffer systems. J Pharm Sci 2002;91:1969-79. http://dx.doi.org/10.1002/jps.10184.

[26] Do Nascimento WCA, Martins MLL. Studies on the stability of protease from Bacillus sp. and its compatibility with commercial detergent. Braz J Microbiol 2006;37:307-11. http://dx.doi.org/10.1590/S1517-83822006000300020. 